\title{
Agent Orange: A Controversy without End
}

\author{
Alvin L. Young* \\ A. L. Young Consulting, Inc., Cheyenne, Wyoming, United States \\ *E-mail: youngrisk@aol.com
}

\begin{abstract}
Confusion and misinformation are common when discussing Agent Orange, a tactical herbicide used in the Vietnam War. This is partially the result of inaccurate news coverage or false information that is purposely spread to deceive veterans. Sensationalized reporting has frequently left the public with a distorted view of what occurred in Vietnam and of the minimal risks related to the use of herbicides in an operational combat environment. However, such a discrepancy between perceived risks and actual risks has also been enhanced by a public policy where historical records and science have been ignored while favoring a policy of "presumptive" compensation promoted by the Agent Orange Act of 1991. The Act has resulted in a narrow focus on tactical herbicides as the key factor in explaining the health risks of Vietnam veterans, ignoring other important risk factors that occurred in the war in Vietnam, namely, widespread endemic tropical diseases and parasites, psychological and physiological impacts of war, and health and lifestyle. Thus, it is not surprising that the controversies surrounding the use of Agent Orange in Vietnam have raged for 40 years. Indeed, more than a million United States veterans and billions of dollars have been spent by the United States Department of Veterans Affairs in providing compensation and health care for unrelated diseases where the vast majorities are not deployment-related health problems or related to herbicide exposure, but rather to aging and quality of life issues.
\end{abstract}

Keywords: Vietnam War, Agent Orange, Agent Orange Act of 1991, tactical herbicides, dioxin/TCDD, veteran health effects, US Department of Veterans Affairs

\section{Situation}

The Agent Orange controversy and associated issues are exceedingly difficult to assess and correct. Why? Although historical records and the appropriate and applicable science provide the basis for good decision making, all too frequently veteran groups, the media, the public, and policy-makers accept the perception of the risks of exposure to toxic chemicals used in Vietnam with little or no regard for actual historic and scientific findings [1]. For example, with the issue of Agent Orange, public discussions and governmental actions have proceeded largely on the assumption, rather than the determination, of widespread substantial exposure to Agent Orange to veterans of the Vietnam War. Indeed, the perception of how Agent Orange was handled and sprayed in Vietnam was based on a false premise [1]. Accordingly, the Department of Veterans Affairs (DVA) has used a "political" definition for exposure for Vietnam veterans; for instance, if a United States (US) veteran served in Vietnam, even for one day, that individual is considered "exposed" to Agent Orange. The veteran is therefore eligible for presumptive compensation for any of 14 diseases determined by the Institute of Medicine to be associated with exposure to Agent Orange and/or its dioxin contaminant and, subsequently legally mandated by the DVA [2].

\section{Background}

Before discussing the role of the media and policy-makers, one must understand what occurred in Vietnam, 1962 - 1975; what countries contributed to combat operations; the defoliants that were used in Vietnam; what was the nature of the traces of dioxin contaminant; how can exposure be assessed; and, lastly a brief discussion of the alleged health impacts.

For the United States, the Vietnam War officially ended on 30 April 1975, but the argument over the use and the legacy of the herbicide known as Herbicide Orange, aka "Agent Orange", lingers to this day. 
A large body of primary historical records and other related data now exist on the use of Agent Orange in Vietnam and are openly available [3]. And as such, they may be used to assess the procedures for spraying herbicides in Vietnam and the data on the fate of Agent Orange and the dioxin in the herbicide. These data provide insight into the distribution and bioavailability of the herbicides and dioxin in the environment and the mechanisms of dissipation and degradation, which provide a basis for assessment of issues of human exposure [4]. Also, available publications now provide a basis on health studies of US Vietnam and Vietnam War Era veterans $[5,6,7,8]$.

\section{Who Served in Vietnam, What Years, and Quantities of Tactical Herbicides}

The nations that sent combat and support troops to Vietnam in support of the Republic of Vietnam (RVN, South Vietnam) during 1962 through 1973 were: The United States with the largest number of military personnel deployed approximately 2,644,000. The Republic of Korea deployed approximately 312,850 military personnel. Australia and New Zealand provided 46,850 combat troops, while Thailand deployed approximately 11,790 personnel from their Navy, Army, and Air Force units [1, 9]. Although no figures were available on either the number of troops deployed by the Republic of Vietnam (RVN, South Vietnam) as Allied Forces, or the Viet Cong Insurgency Forces or the Democratic Republic of Vietnam (North Vietnam), the numbers were also likely in the millions [9]. The DVA considers Vietnam veterans as those "who set foot in Vietnam or who served on a ship while it operated on the inland waterways of Vietnam between 9 January 1962 and 7 May 1975" [2].

The dissemination of tactical herbicides existed in two phases. The "Initial Program Development Phase" was from 29 December 1961 to 18 March 1965 [10]. The aircrews of Operation RANCH HAND became familiar with the weather, terrain and vegetation of South Vietnam, thus developing operational tactics and doctrine necessary to the spraying operation [10]. During this period, a small cadre of US Air Force and Army Special Forces units supported the Army of Vietnam (ARVN) and Air Force of Vietnam (VNAF) [11, 12]. During that time, approximately 3 million liters of the tactical herbicides Pink, Green, and Purple, each containing 2,4,5-T (2,4,5-trichlorophenoxy acetic acid) or a mix of 2,4-D (2,4-dichlorophenoxy acetic acid) and 2,4,5-T were sprayed primarily along roadways and lines of communication $[12,13]$.

In March 1965, the United States assumed a direct and major combat role, changing from a role of training and support for the RVN military forces [10]. This resulted in the United States Department of Defense (DOD) approving the "Operational Phase" of Operation RANCH HAND, which started on 29 March 1965 and ended on 7 January 1971. During this phase, Allied Forces from Australia, Korea, and Thailand joined with US Forces [10,12]. Also, during this period, three tactical herbicides were deployed for various purposes: Agent Orange (2,4-D and 2,4,5-T: 43.33 million liters); Agent White (Picloram, 4amino-3,5,6-trichloropicolinic acid, and 2,4-D: 21.8 million liters); and, Agent Blue (Cacodylic Acid: 6.1 million liters) [13]. It has been estimated that $14 \%$ of the total extent of South Vietnam's woody vegetation were sprayed one or more times [14]. These applications were specifically targeted to reduce ground and forest cover as a means of improving visibility and reducing combat casualties [13].

\section{The Dioxin Contaminant}

The concern with Agent Orange and other tactical herbicides that contained 2,4,5-T herbicide was related to the dioxin contaminant, 2,3,7,8-tetrachlordibenzo- $p$-dioxin, TCDD [13, 15]. The analysis of 525 samples of Agent Orange and 557 samples of 2,4,5-T collected from companies that produced Agent Orange during the same period provided a mean concentration of $1.88 \mathrm{ppm}$ (parts per million) TCDD in Agent Orange $[13,15]$. Considering earlier tactical herbicides, which appeared to contain higher amounts than later batches, the estimated amount of TCDD was between 130 and $144 \mathrm{~kg}$ of TCDD and were likely present in the tactical herbicides used in Vietnam [13, 15]. Based on RANCH HAND and US Army Chemical Corps records, $96-98 \%$ of the TCDD in Agent Orange and other tactical herbicides were sprayed aerially over the jungles and mangrove swamps of Vietnam [15]. The remaining 2 to $4 \%$ would have remained in 'hot spots', i.e., areas where herbicide drums were stored or loaded into the aircraft $[15]$. 


\section{Assessment of Potential Exposure}

Public discussion and government policy have proceeded largely on the assumption that US and Allied Combat Forces and Vietnamese civilians were widely and substantially exposed during the Vietnam War, rather than on a determination of exposure to tactical herbicides and dioxin [2]. However, some efforts with the use of modelling and analytical studies have also been used as potential predictors of exposure to combat forces and Vietnamese [16, 17, 18, 19]. These efforts fall on both sides of the issue of exposure, some indicating a potential for exposure, and others indicating the opposite. The modelling efforts drew from the extensive historical records and detailed studies of dissemination trials of the spray systems. However, one important distinction was that one effort relied upon a validated model used by the US Government and US Industry [17, 18]. The analyses relying on the validated model clearly supported the conclusion that it was highly unlikely that allied ground troops and Vietnamese civilians had direct exposure or were exposed by entering previously sprayed areas [3, 4].

How then can the reports by Vietnam War veterans and Vietnamese civilians of repeated sightings of RANCH HAND aircraft spraying Allied Bases and associated Vietnamese communities be valid? In late 1966, the United States Air Force (USAF) modified a few RANCH HAND UC-123 aircraft to an insecticide-spray configuration. Operation FLYSWATTER commenced on 6 March 1967 [20]. From that date through February 1972, from one to three UC-123 aircraft and crews were used to spray malathion, an organo-phosphate insecticide, for mosquito and malaria control [3, 20]. The low-flying insecticidespraying aircraft were commonly called the 'Silver Bug Birds' because they normally were not camouflaged [20]. These RANCH HAND aircraft routinely sprayed insecticide over military and civilian installations, as well as in areas where military operations were in progress, or about to commence [20]. By 1970, malathion was being applied to 14 airbases and their adjacent South Vietnamese cities, and the re-spray interval had been reduced from every fourteen days to every nine days [20]. Between 1966 and 1972, more than 3.5 million liters of malathion insecticide were sprayed on approximately 6 million hectares of Southern Vietnam [20]. Thus, anecdotal reports of direct spraying of troops and civilians in Vietnam likely reflected the RANCH HAND missions supporting Operation FLYSWATTER [20]. It should be noted that malathion and other insecticides used in Vietnam did not contain TCDD.

A critical review of hundreds of reports and peer reviewed articles on the environmental fate, persistence, on the bioavailability on 2,4,5-T herbicide and its associated dioxin (TCDD) was conducted in 2004 [4, 21]. The findings focused on the issues of density of forest canopies, dislodgeable foliar residues, and the rapid disappearance of the TCDD via photodegradation. The conclusion of this review also concluded that the prospect of widespread prolonged exposure to TCDD from tactical herbicides in ground troops or Vietnamese civilians in Vietnam entering defoliated areas was unlikely because of the environmental dissipation of TCDD, little bioavailability, and the properties of the tactical herbicides [4, 21].

Can these conclusions be validated by field studies conducted in Vietnam? The last mission involving Agent Orange was conducted in Operation RANCH HAND in April 1970 [10]. Teams of scientists selected by and representing the National Research Council of the National Academies of Sciences visited Bien Hoa Province in South Vietnam between September 1971 and August 1972 and collected soil samples in the mangrove areas of Vung-Tau and Rung Sat, and in forestry areas near Ban-MeThuot [22]. Sites were selected at locations where a history of spraying Agent Orange was available and repetitive [22]. Only the herbicides 2,4,5-T and picloram (from Agent White) were detected in most samples and then primarily in the top layer of the soils at concentrations ranging from 3 parts per billion (ppb) to $3 \mathrm{ppm}$ of 2,4,5-T, and less than $0.4 \mathrm{ppm}$ picloram [22]. One of the soil samples collected in October 1971 from a site that had received repeated applications of Agent Orange in the period 19651970, had a soil level of $0.01 \mathrm{ppm}(10 \mathrm{ppb})$ of 2,4,5-T, but no analysis of TCDD was conducted on any of the samples because of the lack of analytical capability to detect it [22]. The National Research Council concluded from their studies in Vietnam: "Claims that the herbicides as they were used during the war have rendered the soil "sterile," permanently or at least for prolonged periods, are without any foundation. It should be noted that these claims were contrary to all existing information for the herbicides in question" [23].

The results of a 2007 study of soil and water samples in the Ma Da area of III Corps, an area repeatedly sprayed with Agent Orange, did not provide evidence that the detected dioxins (mostly 
Octachlorodibenzo- $p$-dioxin, OCDD) that were bound to groundwater colloids were residues from the Vietnam War [24]. A very sophisticated study was reported by Piazza et al in 2010 of the analyses of sediments collected from nine Central Vietnam coastal lagoons [25]. Their conclusions: "Samples from nine Central Vietnam coastal lagoons, together with three soils and sediments collected in two freshwater reservoirs of the Thua Thien-Hue Province, were analyzed for polychlorinated dibenzo-pdioxins and dibenzofurans (PCDD/Fs). Total concentrations were low, from 192 to 2912 pg/g (partsper-trillion) and depth profiles in Tam Giang-Cau Hai sediment cores showed only minor changes over time in PCDD/F input and composition. Octachlorodibenzo-p-dioxin OCDD (not found in Agent Orange) was the prevailing congener (approximately 90\%), indicating combustion as the main PCDD/F source to these coastal systems. The 2,3,7,8-tetrachloro-p-dioxin (TCDD) largely sprayed together with Agent Orange over the study area during the war (1961-1971), was absent or very low. These results support the hypothesis of rapid degradation soon after spraying" [25]. The nine coastal lagoons were near Hue, Da Nang, Quang Ngal, Qui Nhone, Phu Yen, Cam Ranh, Ninh Thuai, and Dam Nai [25].

Are there locations in Vietnam where TCDD residues have persisted? The DOD has expended hundreds of millions of dollars on the disposal of Agent Orange (Operation PACER HO), and on the numerous remediation and environmental monitoring programs conducted at the former sites where Agent Orange was stored at the Naval Construction Battalion Center, Gulfport, Mississippi and Johnston Island, and where Agent Orange was repeatedly sprayed [26, 27]. Hence, it was expected that sites in Vietnam where Agent Orange and other tactical herbicides were stored, and RANCH HAND aircraft serviced would be contaminated [28]. Indeed, analytical studies of these sites confirmed dioxin contamination not only of the soil, but also the adjacent ponds and aquatic organisms [19]. Government Agencies of the United States and Vietnam have continued addressing the contamination and cleanup of these sites [15, 28]. Manh et al reported in 2014 on the extensive serum dioxin analyses of Vietnamese men and concluded that: "people living close to former US airbases might have been exposed to both Agent Orange and other sources of dioxin-like compounds" [29].

\section{A Brief Discussion of Alleged Health Impacts}

An exhaustive evaluation was conducted of the numerous health studies available in the peer-reviewed medical literature and was subsequently reported in the October 2017 issue of the Journal Medical Research Archives [8]. It concluded that: "Under the Agent Orange Act of 1991, the United States Department of Veterans Affairs (DVA) recognizes 14 diseases associated with alleged exposure to Agent Orange, its associated dioxin (TCDD) contaminant, and other tactical herbicides used in combat operations in Vietnam during the war. Although the Institute of Medicine (IOM) provided recommendations to DVA on the medical issues, they were directed by the Act to develop "statistical associations" for human diseases rather than to establish cause and effect relationships. No IOM report determined a consistent, coherent, and credible evidence of a causal connection between a disease and exposure to Agent Orange... The reality is that the current Agent Orange Policy is based on politics driven by public, media, veteran and congressional actions. Special evaluations and considerations must be given to the numerous health studies of Vietnam Era veterans and what they have indicated. [However,] Greater efforts should have been made to study how societal pressures and politics have played a larger role than the efforts of the scientific and medical communities in providing health answers for the Vietnam veterans and the Vietnamese" [8].

If a controversy is based on a preponderance of scientific concerns and these concerns cannot be resolved to the satisfaction of the media and the public, then more scientific studies are needed. However, if scientific and historical data are sufficient, but do not resolve the controversy than it must be concluded that social, political, or legal issues drive the controversy [30]. As noted above, there are now sufficient historical, environmental fate researches, and extensive health studies to suggest that the Agent Orange controversy is not based on the history of the use of tactical herbicides or science, but rather on the devastating human experience of the Vietnam War and on quality of life issues [31].

The actions by the United States Government via the Agent Orange Act of 1991 (Public Law 102-4) provides presumptive compensation in the absence of exposure and causation, an expression by the political system, i.e., the Congress of the United States, intended to acknowledge the sacrifices of the Vietnam Era Veterans. Yet, it creates an unfair condition for veterans who develop diseases and other 
illnesses not associated to Agent Orange or its dioxin contaminant, or to other tactical herbicides [31]. The IOM in their Agent Orange Reports... "have emphasized findings of observational studies and interpretations that might have been enhanced by placing the findings within a biological framework strengthened by greater attention to other lines of evidence... and not just a mere possibility of an association" [32]. Perhaps no better example of this concern has been the findings that 20 percent of 50 Vietnam veterans recently tested by the DVA were infected by slow-killing parasitic worms called liver flukes, known to cause cholangiocarcinoma, a bile-duct cancer [33].

\section{The Role of the Media in Perpetuating Agent Orange Stories}

The media's meshing of medical and scientific evidence with political issues is not surprising given the public history of dioxin and Agent Orange. Substantial reliance on anecdotal stories, often disconnected from the results of studies published in the medical and scientific literature, has generally informed the media and, consequently, the public's understanding of the relative risk to human health posed by exposure to Agent Orange and its associated TCDD [8].

Burkett and Whitley in their 1998 book Stolen Valor, noted that most stories about Agent Orange suffer from the same problems; namely, reporters often don't do the very basic step of checking military records to find out if their subjects are telling the truth about their experiences [34]. While many legitimate veterans who did not exaggerate or lie about their service sincerely believed their health problems were caused by Agent Orange, that belief was not substantiated by the historical records or by scientific studies [34].

Indeed, since 1974 there has been hundreds, if not thousands, of articles describing Vietnam and Vietnam War Era veterans who claim their health problems and those of their children were caused by exposure to Agent Orange [30]. These stories have been the favorite themes of Investigative Reporters whose search was for "the truth", but soon concluded that good stories are best without verifying the facts.

In December 2009, the Chicago Tribune did a 5-part series on "Agent Orange: Lethal Legacy" by Grotto and Jones [35]. One quote from the series:

"In central Indiana, two sisters struggle through another day, afflicted by a painful condition in which their brains are wedged against their spinal cords. They are in their 30s, but their bodies are slowly shutting down. Thousands of miles away, amid the rice paddies of Vietnam, a father holds down his 19year-old daughter as she writhers in pain from a seizure brought on by fluid in her skull, which has been drained four times in the past four years", ... all conditions brought on by exposure to Agent Orange [35].

Scientists have not established that either Agent Orange or the associated dioxin result in human structural birth defects [8]. However, for their 5-part series, Grotto, Jones, Takahashi, and Walker received from the Society of Environmental Journalist First Place for "Outstanding Explanatory Reporting, Print, 2009-2010 [36]. The citation:

The Chicago Tribune's five-part series on Agent Orange's lethal legacy explains in heart-wrenching detail how the weapons of war can keep on maiming and killing decades after hostilities end. The series by reporters Jason Grotto and Tim Jones opens with an unflinching look at the devastating disabilities currently suffered by the children of veterans who fought on opposite sides of the Vietnam War but whose exposure to toxic defoliants condemned their offspring to lives of incurable misery [36].

In May 2011, a reporter for KPHO TV (CBS) in Phoenix, Arizona, carried the story of a simple confession by an Arizona veteran who claimed exposure to Agent Orange when he and other soldiers buried Agent Orange on a US Military Base in South Korea in 1978 [37]. For eight months, the United States Eighth Army Base, Camp Carroll, in southern South Korea, became the center of a probe into the claims by the Arizona veteran. In December 2011, after expending more than a million dollars on investigation and soil chemical analyses, a Republic of Korea-United States Joint Investigation Team concluded that there was no evidence that Agent Orange was ever buried or stored at Camp Carroll [37]. A subsequent scientific article was published on "The Agent Orange Controversy in the Republic of South Korea" [38]. For her series on "Toxic Secrets", Tammy Leitner received in 2012 the prestigious George Foster Peabody Award [39].

In April 2012, the Society of Professional Journalists named Will Doolittle for the series, "Blue Water Veterans," as the winner in its non-deadline reporting category for daily papers with a circulation under 
50,000 . The series of stories reported and written by Doolittle addressed the health problems of veterans "who served on ships in the coastal waters of Vietnam but never set foot on land" [40]. In 2011, IOM reached the conclusion that: "The paucity of scientific data makes it impossible to determine whether Blue Water Navy veterans were exposed to Agent Orange-associated TCDD during the Vietnam War [41]. A subsequent Department of Veterans Affairs Report in August 2013 on the Blue Water Navy Claims examined additional data not reviewed by IOM and concluded: "There is no historical or scientific evidence to conclude that Blue Water Navy Veterans were exposed to Agent Orange" [42].

Thus, as noted, anecdotal stories about the horror of Agent Orange continue in a self-perpetuating series of press and television stories. Perhaps the most egregious example occurred in June 2016 when ProPublica, a non-profit corporation based in New York City that describes itself as an independent non-profit newsroom that produces investigative journalism in the public interest, did an article on Agent Orange [43]. The resulting stories were distributed to more than 90 news "partners" for publication or broadcast [43]. ProPublica's Charles Ornstein had teamed up with colleagues from The Virginian Pilot (a newspaper in Northern Virginia), and the two organizations examined how Agent Orange has impacted the health of Vietnam veterans [43]. To evaluate the impact, they designed a questionnaire to "tell us how the lives of veterans have been affected by exposure to the toxic herbicide". It should not be a surprise that 5,000 self-administered and self-reported questionnaires resulted in hundreds of stories of how the lives of veterans were indeed affected by exposure to the "toxic herbicide" [43]. When challenged by the critics of their reporting, and when provided with the scientific evidence and key facts to the contrary, their response was to ignore such information (personal communication, ALY, 2016). Thus, any attempt by the scientific community to refute these stories was dismissed and the articles were left unaltered to simply spread suspicions and anger within the veteran community. For this "outstanding" piece of investigative journalism on "Reliving Agent Orange", Ornstein, Parris, and Hixenbaugh received the 2016 Online Journalism Award for Topical Reporting [44].

\section{Discussion and Conclusion}

University students enrolled in Journalism are taught from the beginning to avoid the pitfalls of spurious documents and historical forgeries that from their sheer volume and detail invite the credulity of the public. However, with the introduction of the computer and internet websites, anyone with minimal skills may "publish" anything they want without reference to fact or authoritative review, and then distribute such material for perusal by millions of gullible readers. The real difficulty for historians, scientists and journalists is in discriminating between truth and misstatement in documents of composite origin or as provided by an author(s) with a cause. This becomes particularly true for the issues related to Agent Orange. I am reminded of the challenge by the Veterans Administration to assess the validity of allegations that Air Force Reserve personnel were exposed to the dioxin in Agent Orange in RANCH HAND aircraft returned from the Vietnam War, that had been cleaned, refitted and provided to Air Force Reserve Bases in the United States. A website was established by a retired Air Force Reserve Officer and from May 2011 through August 2016, posted more than 900 blog comments to include articles, opinions, allegations, and even negative comments about federal and contract employees of the Agency [45]. Using the vehicles of the blog and internet he sent hundreds of posts to members of the United States Congress, federal agencies, universities and to dozens of newspapers throughout the United States. The power of his website comments, and the distribution of those comments on the internet, successfully forced the Veterans Administration to submit the issue to the Institute of Medicine, who based their decision in favor of the Air Force Reservists on policy and not on science [46].

Almost every aspect of the war in Vietnam has been controversial. Many veterans of the war returned from Vietnam with apprehensions that were manifested by fear about how they were going to re-adjust back into a society that was rapidly changing in its social and economic values [47]. It was a war that generated bitter emotions, and for the men and women who served in the war, regardless of where they were from, the memories of their experiences have lingered [47]. As these men and women have aged and have encountered the diseases common to aging, they have been influenced by the media, public and even the Congress of the United States to believe that many of these diseases were likely caused by their exposure to Agent Orange; apprehensions that have nothing to do with reality [8]. The Veterans 
Administration response to the allegations of health impacts has been driven solely by policy considerations. The facts are that epidemiological studies of Vietnam veterans have not shown that this group has higher mortality or morbidity for the diseases currently presumptively connected to herbicide exposure [48].

Lastly, the issue of financial compensation and health care from the Department of Veterans Affairs cannot be ignored. Once a Vietnam veteran has completed the Department's Agent Orange Registry and found to have a medical condition that is associated by possible exposure to herbicides in Vietnam, that veteran can receive significant compensation and health care for the rest of his or her life [49]. The VA does not release data on number of veterans or the amount of compensation for Agent Orange, but unsubstantiated information suggests that more than a million Vietnam and Vietnam Era veterans are receiving more than $\$ 40$ billion dollars annually. If this is true, there is simply no way that the Congress of the United States will voluntarily end this situation. Too many Vietnam veterans are now dependent upon this compensation and health care.

Thus, the conclusion must be that the policies related to Agent Orange exposure will continue to benefit the journalists, i.e. the stories they write; the politicians, i.e., the veterans votes they receive; and, the veteran, i.e., the compensation and health care received, and no amount of science published in this age of science scrutiny will likely change that situation. We can only hope that ongoing public dialog will result in a more reasoned policy for our Vietnam and Vietnam-Era veterans.

Acknowledgements: The author thanks the US Department of Defense for sponsoring the author to conduct workshops on Agent Orange and the associated dioxin in Hanoi, Viet Nam in 2005 and 2007, and in the Republic of Korea in 2011. The author acknowledges the US Department of Veterans Affairs for funding an effort for the author to spend two years (2012-2014) in the National Archives developing a massive database and preparing reports of documents found on all aspects of the development and testing of the tactical herbicides, their transport, health impacts and policies in the war in Southeast Asia, 1961-1975.

\section{References}

1. AL Young, "A Conflict Between Science and Social Concerns: Agent Orange", Environmental Science and Pollution Research, vol 15 (1), pp. 1-2, 2008.

2. SV Panangala and DT Shedd, "Veterans Exposed to Agent Orange: Legislative History, Litigation, and Current Issues". CRS Report 7-5700, Congressional Research Service, United States Congress, Washington DC, USA, 2014.

3. AL Young, PF Cecil, and JF Guilmartin, "Assessing Possible Exposures of Ground Troops to Agent Orange During the Vietnam War: The Use of Contemporary Military Records", Environmental Science and Pollution Research, vol 11 (6), pp. 349-358, 2004.

4. AL Young, JP Giesy, PD Jones, and M Newton, "Environmental Fate and Bioavailability of Agent Orange and Its Associated Dioxin During the Vietnam War", Environmental Science and Pollution Research, Vol 11 (6): pp. 359-370, 2004.

5. HK Kang, NA Dalager, LL Needham, DG Patterson, Jr., PSJ Lees, K Yates, and GM Matanoski, "Health Status of Army Chemical Corps Vietnam Veterans Who Sprayed Defoliants in Vietnam", American Journal of Industrial Medicine, vol 49, pp. 875-884, 2006.

6. PA Buffler, ME Ginevan, JS Mandel, and DK Watkins, "The Air Force Health Study: An Epidemiologic Retrospective". Annals of Epidemiology, vol 21, pp. 673-687, 2011.

7. ET Chang, P Boffetta, H-O Adami, P Cole, and JS Mandel, "A Critical Review of the Epidemiology of Agent Orange/TCDD and Prostate Cancer", European Journal of Epidemiology, vol 29, pp. 667-723, 2014

8. AL Young, and KL Young, "Agent Orange Use in Vietnam and Alleged Health Impacts: A Review", Medical Research Archives, vol 5 (10), pp.1-20, October 2017.

9. AL Young, and PF Cecil, "Agent Orange Exposure and Attributed Health Effects in Vietnam Veterans", July Supplement, Military Medicine, vol 176 (7), pp. 29-34, 2011.

10. PF Cecil, "Herbicidal Warfare: The RANCH HAND Project in Vietnam". Praeger Special Studies, Praeger Scientific, New York NY, USA, 1986. 
11. RP Fox, "Air Base Defense in the Republic of Vietnam, 1961-1973", Office of Air Force History, United States Air Force, Washington DC, USA, 1979.

12. WA Buckingham, "The Air Force and Herbicides in Southeast Asia, 1961-1971", Office of Air Force History, United States Air Force, Washington DC, USA, 1982.

13. AL Young, "A History of the Development and Procurement of Tactical Herbicides", Chapter 2, IN: "AL Young "The History, Use, Disposition, and Environmental Fate of Agent Orange", Springer Science + Business Media, LLC, New York, NY, USA, 2009.

14. JM Stellman, SD Stellman, R Christian, T Weber, and C Tomasallo, "The Extent and Patterns of Usage of Agent Orange and Other Herbicides in Vietnam", Nature vol 422, pp. 681-687, 2003.

15. AL Young, WJ Van Houten, and WB Andrews, "2 ${ }^{\text {nd }}$ Agent Orange and Dioxin Remediation Workshop, Hanoi, Viet Nam, 18 - 20 June 2007”. Environmental Science and Pollution Research, vol 15 (2), pp. 113-118, 2008.

16. SD Stellman, and JM Stellman, "Exposure opportunity models for Agent Orange, dioxin, and other military herbicides used in Vietnam, 1961-1971", Journal of Exposure Analysis and Environmental Epidemiology, vol 14, pp. 354-362, 2004.

17. JH Ross, A Hewitt, JM Armitage, K Solomon, DK Watkins, and ME Ginevan, "Exposure to TCDD from base perimeter applications of Agent Orange in Vietnam", Science of the Total Environment, vol 511, pp. 82-90, 2015.

18. JM Armitage, ME Ginevan, A Hewitt, JH Ross, DK Watkins, and KR Solomon, "Environmental fate and dietary exposures to humans to TCDD as a result of spraying of Agent Orange in upland forests of Vietnam", Science of the Total Environment, vol 506-570, pp. 621-630, 2015.

19. DT Pham, HM Nguyen, TG Bovin, A Zajacova, SV Huzurbazar, and HL Bergman, "Predictors for dioxin accumulation in residents living in Da Nang and Bien Hoa, Vietnam, many years after Agent Orange Use", Chemosphere vol 118, pp. 277-283, 2015

20. PF Cecil, and AL Young, "Operation FLYSWATTER: A War Within a War. Environmental Science and Pollution Research, vol 15 (1), pp. 3-7, 2008.

21.TL Lavy, "Human Exposure to Phenoxy Herbicides", Monograph published by the Agent Orange Projects Office, Department of Medicine and Surgery, Veterans Administration, Washington DC, USA, 1987.

22. GE Blackman, JD Fryer, A Lang, and M Newton, "Persistence and Disappearance of Herbicides in Tropical Soils", Part B: "Working Papers. The Effects of Herbicides in South Vietnam", National Research Council, National Academies of Sciences, Washington DC, USA, 1974.

23. NRC, "The Effects of Herbicides in South Vietnam", Part A: "Summary and Conclusions", Committee on the Effects of Herbicides in South Vietnam, National Research Council, National Academies of Sciences, Washington DC, USA, 1974.

24. T Hofman, and A Wendelborn, "Colloidal Facilitated Transport of Polychlorinated Dibenzo- $p$-dioxins and Dibenzofurans (PCDD/Fs) to the Groundwater of Ma Da Area, Vietnam", Environmental Science and Pollution Research, vol 14 (4), pp. 223-224, 2007.

25. R Piazza, S Giuliani, LG Bellucci, C Mugnai, NH Cu, DH Nhon, M Vecchiato, S Romano, and M Frignani, "PCDD/Fs in Sediments of Central Vietnam Coastal Lagoons: In Search of TCDD", Marine Pollution Bulletin vol 60 (12), pp. 2303-2310, 2010.

26. AL Young, "Monitoring Studies of Former Agent Orange Storage Sites in Mississippi and Johnston Island", Chapter 3, IN: AL Young, "The History, Use, Disposition, and Environmental Fate of Agent Orange", Springer Science + Business Media, LLC, New York NY, USA, 2009.

27. AL Young, and M Newton, "Long Overlooked Historical Information on Agent Orange and TCDD Following Massive Applications of 2,4,5-T-Containing Herbicides, Eglin Air Force Base, Florida", Environmental Science and Pollution Research, vol 11 (4), pp. 209-221, 2004.

28. AL Young, and WB Andrews, "Agent Orange and Dioxin Remediation Workshop, Hanoi, Viet Nam, 16 - 18 August 2005", Environmental Science and Pollution Research, vol 12 (6), pp. 391-392, 2005.

29. HD Manh, T Kido, R Okamoto, S Xian Liang, LT Anh, S Supratman, S Maruzeni, M Nishijo, H Nakagawa, S Honma, T Nakano, T Takasuga, DD Nhu, NN Hung, and L Ke Son, "Serum Dioxin Levels in Vietnamese Men more than 40 years after Herbicide Spraying", Environmental Science and Technology, vol 48, pp. 3496-3503, 2014.

30. AL Young, "Social Assessment of the Agent Orange Controversy, IN: Chapter 10, AL Young and GM Reggiani (eds), "Agent Orange and Its Associated Dioxin: Assessment of a Controversy", Elsevier Science Publishers, The 
Netherlands, 1988.

31. AL Young, "Can There be a Satisfactory End to the Agent Orange Controversy", Postlude. IN: AL Young, "The History, Use, Disposition, and Environmental Fate of Agent Orange", Springer Science + Business Media, LLC, New York NY, USA, 2009.

32. IOM, "Improving the Presumptive Disability Decision-Making Process for Veterans", The Institute of Medicine, The National Academies Press, Washington DC, USA, 2008, www.nap.edu.

33. MOAA, "VA Studies Vietnam Vets for Exposure to Cancer-Causing Parasite", Military Officers Association of America Magazine, November 30, 2017.

34. BG Burkett, and G Whitley, "Stolen Valor: How the Vietnam Generation Was Robbed of Its Heroes and Its History", Chapter 32, "The Myth of Agent Orange", Verity Press, Inc., Dallas, TX, USA,1998.

35. J Grotto, and T Jones, "Agent Orange: Lethal Legacy", 5-Part Series, Chicago Tribune, Chicago IL, USA, 2009. 36. www.sej.org/initiatives/winner-sej- $9^{\text {th }}$-annual-awards, 2010.

37 WT Ham, "Team Concludes Agent Orange Investigation in Korea", Eighth Army Public Affairs, December 29, 2011.

38. AL Young, and KL Young, "The Agent Orange Controversy in the Republic of South Korea", Environmental Pollution and Protection, vol 1(2), pp. 69-80, 2016.

39. www.azfamily.com/story/14849292/tammy-leitner, 2012.

40. Post-Star, "Doolittle wins national award for Agent Orange stories", Staff Report, Post-Star Newspaper, Warren NY, USA, April 10, 2012.

41. IOM, "Blue Water Navy Veterans and Agent Orange Exposure", Health and Medicine Division, National Academies of Sciences, Washington DC, USA, 2011.

42. AL Young and KL Young, "Discussion Points Concerning Blue Water Navy Claims", Agent Orange Brief No. 2 , Compensation Service, Department of Veterans Affairs, Washington DC, USA, 2013.

43. C Ornstein, T Parris Jr., S Wei, and M Hixenbaugh, "Reliving Agent Orange: What the Vietnam Vets have to Say (17 June 216); Dr. Orange: The Secret Nemesis of Sick Vets (26 October 2016). ProPublica, New York NY; and the Virginian Pilot, Norfolk VA, USA, 2016.

44. OJA, "Online Journalism Award for the Agent Orange series: "Reliving Agent Orange", winner for the 2016 Topical Reporting Medium Newsroom, 2016.

45. W Carter, Webmaster (2011-2016): www.c123cancer.blogspot.com.

46. IOM, "Post-Vietnam Dioxin Exposure in Agent Orange-Contaminated C-123 Aircraft", Institute of Medicine, Board on the Health of Select Populations. National Academies of Science, Washington DC, USA, 2016.

47. R Strayer, and L Ellenhorn, "Vietnam Veterans: A Study Exploring Adjustment Patterns and Attitudes", Journal of Social Issues, vol 31 (4), pp. 81-93, 1975.

48. M Brown, "Science Versus Policy in Establishing Equitable Disability Compensation Policy". July Supplement 2011, Military Medicine, vol 176 (7), pp. 35-40, 2011.

49. VHA Directive 1302 (Updated Dec 7, 2016): Agent Orange Registry Program. Veterans Health Administration, Department of Veterans Affairs, Washington DC, USA, 2016. 